\title{
Koncept i mjerenje kvalitete zdravstvenih usluga
}

2IIIIIIIIIIIIIIIIIIIIIIIIIIIIIIIIIIIIIIIIIIIIIIIIIIIIIIIIIIIIIIIIIIIIIIIIIIIIIIIIIIIIIIIIIIIIIIII

1 Suzana Marković

1 Irena Regent Turkalj

2 Aleksandar Racz

1 Fakultet za menadžment u turizmu i ugostiteljstvu, Opatija

2 Zdravstveno veleučilište, Zagreb

\section{Sažetak}

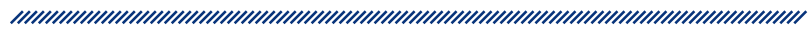

Uvod. Koncept kvalitete zdravstvenih usluga istražuje se već više od dva desetljeća, ali u znanstvenoj i stručnoj praksi u RH još uvijek postoji mali broj radova u kojima se istražuje i mjeri razina zadovoljstva korisnika zdravstvenih usluga.

Ciljevi rada su bili_definirati koncepte kvalitete zdravstvenih usluga, istražiti modele i metode za mjerenje kvalitete zdravstvenih usluga, analizirati dosadašnja istraživanja kvalitete zdravstvenih usluga stranih i domaćih autora s naglaskom na istraživanja unutar zdravstvenog sustava, istražiti dosadašnja istraživanja i mjerenja kvalitete zdravstvenih usluga te primjenjivost modela SERVQUAL kao najčešće upotrebljavanog modela za mjerenje kvalitete usluga.

Metode. Primijenjen je konceptualni pristup istraživanju u kojemu su koncept kvalitete usluga s naglaskom na koncept kvalitete zdravstvenih usluga i zadovoljstva korisnika obrađeni i izneseni usustavljeno s teorijskog stajališta, pri čemu su upotrijebljeni sekundarni izvori podataka.
Rezultati. Rad donosi sustavni_pregled temeljnih koncepata kvalitete zdravstvenih usluga, kao i modela mjerenja kvalitete zdravstvenih usluga s naglaskom na primjenjivost modela SERVQUAL.

Zaključak. Rezultati ovog istraživanja potvrdili su da je koncept zdravstvenih usluga višedimenzionalan te je još jednom potvrđeno da je uz primjenu modela SERVQUAL moguće na jednostavan i učinkovit način saznati očekivanja, potrebe i želje korisnika zdravstvenih ustanova, kao i njihove stavove o dobivenim uslugama, a zatim ih iskoristiti u svrhu kreiranja kvalitetne ponude.

Ključne riječi: kvaliteta zdravstvenih usluga, zadovoljstvo klijenta, lojalnost, model SERVQUAL

Datum primitka: 15.02.2018.

Datum prihvaćanja: 20.03.2018.

DOI: $10.24141 / 1 / 4 / 1 / 5$

Adresa za dopisivanje:

Prof.dr. Suzana Marković

Fakultet za menadžment u turizmu i ugostiteljstvu

Sveučilišta u Rijeci

Primorska 42, p.p. 97, 51410 Opatija

suzanam@fthm.hr 


\section{Uvod - problem istraživanja}

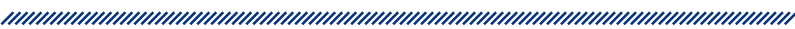

Kvalitetna zdravstvena zaštita, u skladu sa zdravstvenim stanjem i općeprihvaćenim stručnim standardima, jedno je od temeljnih ljudskih prava. Koncept kvalitete zdravstvenih usluga neprekidno napreduje i transformira se ovisno o zainteresiranosti za njega i razini uključenosti svih sudionika (medicinskog osoblja, pacijenata, financijera, zakonodavca) u područje upravljanja kvalitetom usluge. U skladu s time koncept kvalitete zdravstvenih usluga istražuje se već više od dva desetljeća, ali u znanstvenoj i stručnoj praksi u RH još uvijek postoji mali broj radova u kojima se istražuje i mjeri razina zadovoljstva korisnika zdravstvenih usluga. Upravo je zato nužno je stvoriti odgovarajuću i znanstveno provjerenu sliku o potrebama, očekivanjima, percepcijama i zadovoljstvu, sve da bi se zdravstvena politika počela mijenjati u korist korisnika zdravstvenih usluga.

Jedan je od osnovnih problema koji se pokušava riješiti kako mjeriti kvalitetu zdravstvene usluge i zadovoljstvo korisnika usluga. Zbog toga je korisno istraživati teorijske i empirijske spoznaje te sustavno formulirati i javnosti predstaviti rezultate istraživanja o kvaliteti zdravstvenih usluga s posebnim naglaskom na model SERVQUAL kao često upotrebljavan model za mjerenje kvalitete zdravstvenih usluga.

Slijedom navedenog, u ovom radu primijenjen je konceptualni pristup istraživanju u kojemu su koncept kvalitete usluga s naglaskom na kvalitetu zdravstvenih usluga i zadovoljstva korisnika obrađeni i izneseni usustavljeno s teorijskog stajališta, pri čemu su upotrijebljeni sekundarni izvori podataka. Konkretno, na temelju analize relevantnih domaćih i stranih znanstvenih i stručnih radova iznosi se pregled temeljnih koncepata kvalitete zdravstvenih usluga, kao i modeli mjerenja kvalitete zdravstvenih usluga, očekivanja i percepcije te zadovoljstva korisnika.

Drugi dio rada odnosi se na rezultate empirijskog istraživanja koji se temelje na prikupljanju primarnih podataka metodom ispitivanja s pomoću anketnog upitnika oblikovanog na temelju modificiranog modela SERVQUAL.

\section{Cilj istraživanja}

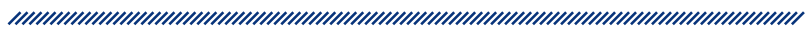

Ciljevi ovog istraživanja bili su:

1. definirati koncept kvalitete zdravstvenih usluga

2. istražiti modele i metode za mjerenje kvalitete zdravstvenih usluga

3. analizirati dosadašnja istraživanja kvalitete zdravstvenih usluga stranih i domaćih autora s naglaskom na istraživanja unutar zdravstvenog sustava

4. istražiti dosadašnja istraživanja i mjerenja kvalitete zdravstvenih usluga

5. analizirati primjenjivost modela SERVQUAL kao najčešće upotrebljavanog modela za mjerenje kvalitete usluga.

\section{Metode istraživanja}

U radu su primijenjene sljedeće znanstveno-istraživačke metode: induktivna i deduktivna metoda, metoda analize i sinteze, metoda apstrakcije i konkretizacije, metoda generalizacije i specijalizacije, metoda dokazivanja i opovrgavanja, povijesna metoda, komparativna metoda, metoda klasifikacije, empirijska metoda te metoda deskripcije i kompilacije.

\section{Rezultati}

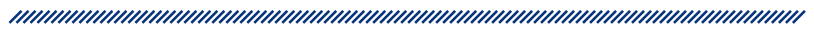

\subsection{Koncept kvalitete zdravstvenih usluga}

Zadovoljiti potrebe korisnika zdravstvenih usluga nije jednostavno jer zadovoljstvo korisnika takvom uslugom $\mathrm{s}$ jedne strane ovisi o zadovoljstvu pružateljem usluge kao pojedincem (liječnik ili bilo koji drugi zdravstveni djelatnik), a s druge o širem ustrojstvu zdravstvenog sustava. U zdravstvu se može govoriti o: kvaliteti za 
korisnika (ono što pacijent traži), profesionalnoj kvaliteti (procjeni liječnika i drugih stručnjaka jesu li zadovoljene potrebe pacijenta i jesu li usluge pružene tehnički ispravno i uz primjenu odgovarajuće procedure) te kvaliteti za menadžment (ocjenjuje se učinkovitost i produktivnost unutar zadanih ograničenja i smjernica).

Svjetska zdravstvena organizacija definira kvalitetu kao „zdravstvenu uslugu koja po svojim obilježjima zadovoljava zadane ciljeve, a sadašnjim stupnjem znanja i dostupnim resursima ispunjava očekivanja bolesnika da dobije najbolju moguću skrb uz minimalni rizik za njegovo zdravlje i blagostanje"1. Donabedian² navodi da je „kvalitetna zdravstvena skrb ona od koje se očekuje najveća dobrobit za pacijenta", a Grant smatra da je „kvalitetna medicinska zaštita potencijal elemenata medicinske zaštite za ostvarenje opravdanih medicinskih i nemedicinskih ciljeva bolesnika i liječnika"3.

Lohr i Schroeder ${ }^{4}$ smatraju da je „kvalitetna medicinska zaštita onaj stupanj zaštite pri kojem zdravstvene usluge za pojedinačne pacijente i populaciju povećavaju vjerojatnost željenih zdravstvenih ishoda i koji je u suglasju s tekućim profesionalnim znanjem". Još precizniju definiciju kvalitete u zdravstvu daje Øvretveit, koji navodi da je „kvalitetna medicinska zaštita potpuno zadovoljenje potreba onih kojima su najviše potrebne zdravstvene usluge, po najmanjem trošku za organizaciju, a unutar ograničenja i smjernica koje postavljaju zdravstvene vlasti i financijeri"'s.

Kvaliteta zdravstvene skrbi može se opisati i kao „stupanj do kojega pružene zdravstvene usluge u skladu sa sadašnjim profesionalnim znanjem (definiranim standardima) povećavaju vjerojatnost nastanka željenih rezultata"6. Svjetska zdravstvena organizacija definira kvalitetu zdravstvenih usluga kao „stupanj ostvarivosti ciljeva zdravstvenih sustava koji vode poboljšanju zdravlja i odgovaraju potrebama i očekivanjima stanovništva" . Najčešće se kao temeljne dimenzije zdravstvene skrbi i općenito zdravstvenih sustava izdvajaju: učinkovitost, djelotvornost, dostupnost, sigurnost, jednakost, opravdanost, prikladnost, pravodobnost, prihvatljivost, odgovornost, zadovoljstvo, usredotočenost na pacijenta, poboljšanje, kontinuitet skrbi i druge, pri čemu su dimenzije učinkovitosti i djelotvornosti uključene u gotovo svaku definiciju kvalitete ${ }^{8}$. Prema Woodwardu, čimbenici su koji utječu na kvalitetu zdravstvene skrbi: organizacija zdravstvenog sustava, raspoloživo osoblje, uvođenje promjena, pristup razvijenoj tehnologiji, raspoloživo znanje i vještine, povezanost obrazovnog sustava i zdravstvenog sektora te sposobnost apsorpcije i usvajanja novih znanja?
Postoje različiti pristupi u klasificiranju razina kroz koje se kvaliteta zdravstvene skrbi može vrednovati (mjeriti). U pristupu Donabediana navode se četiri razine $u$ čijem su središtu (prva razina) usluge i liječnici te ostali pružatelji, a kvalitetu mjeri s gledišta tehničke izvedbe i upravljanja međuljudskim odnosima te opravdanost usluge i potrebne vještine za njezino provođenje procjenjuje usporedbom najbolje prakse ${ }^{2,10}$. Drugu razinu predstavljaju koristi od pružene skrbi, uz posebno isticanje poželjnih atributa okruženja u kojima se djeluje. Treća razina odnosi se na implementaciju zdravstvenih usluga u kojoj sudjeluju pacijenti i pružatelji usluga. Posljednja, četvrta razina odnosi se na zdravstvenu skrb pruženu čitavoj zajednici, pri čemu se osvrće na socijalnu raspodjelu zdravstvenih usluga i njihovu kvalitetu.

Drukčiji pristup mjerenju kvalitete imali su Braithwaite, Healy i Dwan, čije je temeljno polazište bilo da se kvaliteta najbolje može postići, mjeriti i održati primjenom mehanizama koji odgovaraju kontekstu, ponašanju $i$ kulturi uključenih te su predložili piramidu regulacijskog okvira koja se proteže od stroge regulacije do tržišnih mehanizama, ističući pri tome važnost sigurnosti pacijenata. Idealno, svaki sustav procjene kvalitete trebao bi uključiti elemente strukture, procesa i ishoda, s obzirom na to da elementi označuju različita gledišta o zdravstvenoj skrbi u sustavu zdravstva ${ }^{11}$.

Øvretveit kvalitetu zdravstva promatra s tri različita gledišta: (1) pacijentova, (2) profesionalnog i (3) upravljačkog. Pacijenti traže kvalitetnu uslugu, profesionalci teže ka što kvalitetnijem zadovoljavanju pacijentovih potreba te korektnom i pravilnom obavljanju procedura potrebnih za pružanje kvalitetnih usluga ${ }^{5,12}$. Kvaliteta upravljanja uključuje učinkovitu i djelotvornu uporabu raspoloživih resursa radi zadovoljavanja potreba pacijenata. Slično predlaže i Cholewka - promatranje kvalitete zdravstvene skrbi kroz tri međusobno povezana područja: tehničko, interpersonalno i organizacijsko ${ }^{13}$.

\subsection{Mjerenje kvalitete zdravstvenih usluga}

Mjerenje kvalitete usluga u suvremenom poslovnom okruženju zauzima sve veću pozornost i u menadžmentu i u marketingu. Pružatelji usluga žele ih pružiti što kvalitetnije, podići ih na višu razinu. Da bi se to postiglo, kvalitetu je potrebno mjeriti pa se problem mjerenja kvalitete usluge javio u samim začetcima znanosti o kvaliteti. Na kvalitetu usluga ne utječe samo rezultat, tj. zadovoljstvo ili nezadovoljstvo potrošača primljenom uslugom, nego i sam proces pružanja usluge u kojemu potrošač može sam aktivno sudjelovati. Taj proces pru- 
žanja usluge također je važan za postizanje konačnog zadovoljstva pruženom uslugom. Dakle, dva su ključna elementa u mjerenju kvalitete usluga identifikacija zahtjeva potrošača i očekivanja o kvaliteti usluga.

Problem je kod mjerenja kvalitete usluge što nema jasnih i mjerljivih parametara budući da su usluge, kako je već objašnjeno, neopipljive, nedjeljive, promjenjive i heterogene. Jedan je od modela koja sadrži poželjne karakteristike usluga ljestvica SERVQUAL, a Parasuraman, Berry i Zeithaml razvili su kao polaznu osnovu za mjerenje kvalitete usluga model SERVQUAL ili Service Quality. Ovaj model kvalitetu usluge promatra kao višedimenzionalni konstrukt koji se izvorno sastojao od deset dimenzija ${ }^{14}$, a naknadno su broj dimenzija smanjili na pet ${ }^{15}$ : pouzdanost (engl. reliability), sigurnost (engl. assurance), opipljivost (engl. tangibles), razumijevanje (engl. empathy) i odaziv (engl. responsiveness) (tablica 1). Svrha je primjene ovog instrumenta u pronalaženju tzv. jaza (engl. gap - raskorak, razlika) između očekivanja korisnika usluge i njegove percepcije o danoj usluzi. Na temelju kritike modela SERVQUAL Cronin i Taylor razvili su model nazvan SERVPERF - Service Performance. Ovaj novi instrument za mjerenje kvalitete usluge, razvijen na temelju istraživanja pojma i mjerenja kvalitete usluga i povezanosti kvalitete usluga sa zadovoljstvom korisnika i namjerama ponovne kupnje, predstavlja zapravo modificirani SERVQUAL. No ovaj je instrument jednostavniji jer uključuje samo pitanja o performansama. Naime, Cronin i Taylor tvrde da je mjera kvalitete usluge koja se temelji na mjerenju izvedbe (performansi) bolji model mjerenja kvalitete usluga od usporedbe percepcije izvedbe s očekivanjima, što je osnova SERVQUAL-a. Model SERVPERF temelji se na 22 tvrdnje kojima se utvrđuje izvedba, a mjeri se na Likertovoj ljestvici od sedam stupnjeva.

\subsection{Pregled dosadašnjih istraživanja u području mjerenja kvalitete zdravstvenih usluga}

Tablica 2 donosi pregled dosadašnjih istraživanja u području mjerenja kvalitete zdravstvenih usluga.

Babakus i Mangold pioniri su u primjeni modela SERVQUAL u mjerenju kvalitete usluga u zdravstvu. Njihovo empirijsko istraživanje ispitivalo je pouzdanost i vrijednost instrumenta. Ljestvice očekivanja i percepcije rezultirale su kao jednodimenzionalni konstrukti te je dokazano da se mogu uspješno primijeniti za procjenu veličine jaza između pacijentovih očekivanja i percepcije. Upravo iz tog razloga autori su ocijenili model SERVQUAL kao sažet i praktičan instrument koristan za procjenu kvalitete zdravstvenih usluga te predložili daljnja istraživanja i evaluaciju instrumenta ${ }^{17}$.

Najvažniji rezultat istraživanja kvalitete bolničkih usluga koje je Lam proveo u Hong Kongu jest potvrda da se SERVQUAL može primjenjivati kao konzistentan i pouzdan instrument. Međutim, predloženih pet dimenzija SERVQUAL-a nije dokazano te je svaka tvrdnja promatrana zasebno. Osim za dimenziju koja se odnosi na opipljive elemente, za sve su ostale očekivanja bila veća od percipirane razine kvalitete pružene usluge ${ }^{18}$.

Andaleeb je u svojem istraživanju uspoređivao kvalitetu usluga pruženih u javnim i privatnim bolnicama u Bangladešu ${ }^{19}$. Pretpostavio je da bi privatne bolnice, s obzirom na to da nisu subvencionirane i ovisne su o prihodu od pacijenata, trebale biti više motivirane od javnih bolnica da pacijentima pruže očekivanu kvalitetu usluga. Ova je pretpostavka podržana. Percipirana kvaliteta zdravstvenih usluga i ključne sociodemografske karakteristike također su upotrijebljene da bi se predvi-

\begin{tabular}{|c|c|c|}
\hline DIMENZIJA & OPIS & BROJ TVRDNJI \\
\hline Pouzdanost & $\begin{array}{l}\text { Sposobnost pouzdanog i točnog } \\
\text { obavljanja obećane usluge }\end{array}$ & 4 \\
\hline Sigurnost & $\begin{array}{c}\text { Znanje i ljubaznost zaposlenika } \\
\text { i njihova sposobnost ulijevanja } \\
\text { povjerenja }\end{array}$ & 5 \\
\hline Opipljivost & $\begin{array}{l}\text { Izgled fizičkih objekata, opreme, } \\
\text { osoblja i komunikacijskih materijala }\end{array}$ & 4 \\
\hline Razumijevanje & $\begin{array}{l}\text { Brižnost i individualizirana pažnja } \\
\text { prema kupcima }\end{array}$ & 5 \\
\hline Odaziv & $\begin{array}{l}\text { Brza usluga i spremnost za } \\
\text { pomaganje korisnicima }\end{array}$ & 4 \\
\hline
\end{tabular}


Tablica 2. Pregled dosadašnjih istraživanja u području mjerenja kvalitete zdravstvenih usluga

\begin{tabular}{|c|c|c|c|}
\hline$\overline{\text { AUTOR }}$ & KONCEPTI & $\overline{\text { MODEL }}$ & $\overline{\text { DIMENZIJE }}$ \\
\hline Babakus i Mangold (1992) & Kvaliteta usluga & Modificirani SERVQUAL & $\begin{array}{l}\text { Jednodimenzionalni } \\
\text { konstrukt }\end{array}$ \\
\hline Lam (1997) & Kvaliteta usluga & SERVQUAL & $\begin{array}{l}\text { Jednodimenzionalni } \\
\text { konstrukt }\end{array}$ \\
\hline Andaleeb (2000) & Kvaliteta usluge & Modificirani SERVQUAL & $\begin{array}{l}\text { Odgovornost } \\
\text { Sigurnost } \\
\text { Komunikacija } \\
\text { Disciplina } \\
\text { Bakšišs }\end{array}$ \\
\hline Lee i sur. (2000) & Kvaliteta usluga & Modificirani SERVQUAL & $\begin{array}{l}\text { Pouzdanost } \\
\text { Profesionalnost } \\
\text { Razumijevanje } \\
\text { Sigurnost } \\
\text { Srž medicinske usluge } \\
\text { Odgovornost } \\
\text { Opipljivost }\end{array}$ \\
\hline Sohail (2003) & Kvaliteta usluge & Modificirani SERVQUAL & $\begin{array}{l}\text { Opipljivost } \\
\text { Pouzdanost } \\
\text { Odgovornost } \\
\text { Sigurnost } \\
\text { Razumijevanje }\end{array}$ \\
\hline Bajto i Kondić (2005) & Kvaliteta usluga & $\begin{array}{c}\text { Modificirani SERVQUAL } \\
\text { (SERVPERC) }\end{array}$ & Nije utvrđeno \\
\hline Pakdil i Harwood (2005) & $\begin{array}{c}\text { Kvaliteta usluga } \\
\text { Zadovoljstvo pacijenta }\end{array}$ & SERVQUAL & Nije utvrđeno \\
\hline Ramsaran-Forward (2005) & Kvaliteta usluga & SERVQUAL & $\begin{array}{c}\text { Opipljivost } \\
\text { Pouzdanost } \\
\text { Odgovornost } \\
\text { Sigurnost } \\
\text { Razumijevanje } \\
\text { Glavne medicinske usluge } \\
\text { Profesionalizam }\end{array}$ \\
\hline Karassavidou i sur. (2009) & Kvaliteta usluga & SERVQUAL & $\begin{array}{l}\text { Ljudski aspekt } \\
\text { Fizičko okruženje i } \\
\text { infrastruktura } \\
\text { Pristup }\end{array}$ \\
\hline Petrovici i Phillips (2009) & Kvaliteta usluga & SERVHOSP & $\begin{array}{c}\text { Opipljivost } \\
\text { Razumijevanje } \\
\text { Odgovornost } \\
\text { Ambijent } \\
\text { Upravljanje rizicima } \\
\text { Pouzdanost }\end{array}$ \\
\hline Ozretić Došen i Škare (2010) & Kvaliteta usluga & SERVQUAL & $\begin{array}{c}\text { Opipljivi elementi } \\
\text { Pouzdanost } \\
\text { Odgovornost } \\
\text { Sigurnost } \\
\text { Razumijevanje za korisnika }\end{array}$ \\
\hline Yeşilada i Direktör (2010) & Kvaliteta usluga & SERVQUAL & $\begin{array}{l}\text { Pouzdanost - povjerenje } \\
\text { Razumijevanje } \\
\text { Opipljivost }\end{array}$ \\
\hline
\end{tabular}




\section{Tablica 2. Pregled dosadašnjih istraživanja u području mjerenja kvalitete zdravstvenih usluga}

\begin{tabular}{|c|c|c|c|}
\hline AUTOR & KONCEPTI & MODEL & $\overline{\text { DIMENZIJE }}$ \\
\hline Brahmbhatt i sur. (2011) & Kvaliteta usluga & Modificirani SERVQUAL & $\begin{array}{c}\text { Fizički aspekt } \\
\text { Pouzdanost (obećanja, } \\
\text { dostupnost informacija) } \\
\text { Susreti (odgovornost, } \\
\text { razumijevanje) } \\
\text { Proces } \\
\text { Politika bolnice }\end{array}$ \\
\hline Huseinspahić (2011) & $\begin{array}{c}\text { Kvaliteta usluga } \\
\text { Zadovoljstvo pacijenata }\end{array}$ & Modificirani SERVQUAL & $\begin{array}{c}\text { Tehničke dimenzije } \\
\text { (ozdravljenje/liječenje, } \\
\text { kvaliteta života oboljeloga, } \\
\text { izgradnja svijesti i } \\
\text { odgovornosti oboljeloga) } \\
\text { Funkcionalne dimenzije } \\
\text { (opipljivost, pouzdanost, } \\
\text { susretljivost, sigurnost, } \\
\text { empatija) }\end{array}$ \\
\hline Wu (2011) & $\begin{array}{c}\text { Kvaliteta usluga } \\
\text { Zadovoljstvo } \\
\text { Lojalnost }\end{array}$ & Modificirani SERVQUAL & $\begin{array}{c}\text { Imidž brenda bolnice } \\
\text { Kvaliteta usluge } \\
\text { Zadovoljstvo pacijenta } \\
\text { Namjera ponovnog dolaska }\end{array}$ \\
\hline Kumaraswamy (2012) & Kvaliteta usluga & Modificirani SERVQUAL & $\begin{array}{l}\text { Ponašanje liječnika } \\
\text { Podrška osoblja } \\
\text { Atmosfera } \\
\text { Operativna izvedba }\end{array}$ \\
\hline Lei i Jolibert (2012) & $\begin{array}{c}\text { Kvaliteta usluga } \\
\text { Zadovoljstvo } \\
\text { Lojalnost }\end{array}$ & Modificirani SERVQUAL & $\begin{array}{l}\text { Jednodimenzionalni } \\
\text { konstrukt }\end{array}$ \\
\hline Rahman i Kutubi (2013) & $\begin{array}{c}\text { Kvaliteta usluga } \\
\text { Zadovoljstvo pacijenata }\end{array}$ & Modificirani SERVQUAL & $\begin{array}{c}\text { Pouzdanost } \\
\text { Odgovornost } \\
\text { Sigurnost } \\
\text { Opipljivost } \\
\text { Komunikacija } \\
\text { Razumijevanje } \\
\text { Značajke procesa } \\
\text { Trošak } \\
\text { Pristup } \\
\text { Usluge naplate } \\
\text { Ishod liječenja }\end{array}$ \\
\hline $\begin{array}{l}\text { Krishnamoorthy i Srinivasan } \\
\text { (2014) }\end{array}$ & $\begin{array}{l}\text { Kvaliteta usluga } \\
\text { Zadovoljstvo }\end{array}$ & Vlastita ljestvica & $\begin{array}{c}\text { Medicinska usluga } \\
\text { Razumijevanje } \\
\text { Prijam } \\
\text { Otpust } \\
\text { Fizičko okruženje } \\
\text { Jednakost } \\
\text { Infrastruktura } \\
\text { Opipljivost } \\
\text { Medicinska njega } \\
\text { Dostupnost }\end{array}$ \\
\hline
\end{tabular}




\begin{tabular}{|c|c|c|c|}
\hline AUTOR & KONCEPTI & MODEL & DIMENZIJE \\
\hline Peprah i Atarah (2014) & $\begin{array}{c}\text { Kvaliteta usluga } \\
\text { Zadovoljstvo }\end{array}$ & Modificirani SERVQUAL & $\begin{array}{c}\text { Opipljivost } \\
\text { Pouzdanost } \\
\text { Komunikacija (međuljudski } \\
\text { odnosi) } \\
\text { Razumijevanje } \\
\text { Sigurnost } \\
\text { Odgovornost }\end{array}$ \\
\hline Mečev i Goleš Kardum (2105) & Kvaliteta usluga & SERVQUAL & $\begin{array}{l}\text { Pouzdanost, odgovornost i } \\
\text { razumijevanje (jedan faktor) } \\
\text { Opipljivost } \\
\text { Sigurnost }\end{array}$ \\
\hline Zarei i sur. (2015) & $\begin{array}{c}\text { Kvaliteta usluga } \\
\text { Zadovoljstvo }\end{array}$ & Modificirani SERVPERF & $\begin{array}{c}\text { Kvaliteta fizičkog okruženja } \\
\text { Kvaliteta sustava } \\
\text { Kvaliteta interakcije } \\
\text { Troškovi }\end{array}$ \\
\hline
\end{tabular}

dio izbor javne ili privatne ustanove. Utvrdio je da percipirana kvaliteta zdravstvenih usluga ima izravan utjecaj na namjeru ponašanja, uključujući zadovoljstvo, preporuke, izbor, korištenje i slično.

Za razliku od većine drugih autora koji su SERVQUAL testirali iz perspektive pacijenta, Lee i suradnici svoje su istraživanje proveli na uzorku liječnika. Ovaj pristup smatraju opravdanim ako se krene od pretpostavke da korisnici usluga (pacijenti) često nisu sposobni procijeniti ključne dimenzije medicinskih usluga i iz tog razloga ne mogu toliko pridonijeti dizajniranju djelotvornoga zdravstvenog sustava. U svojem su istraživanju utvrdili da se dimenzije kvaliteta usluga ne mogu odvojiti u specifičnom kontekstu medicinskih usluga te sugerirali potrebu razvoja novoga prikladnijeg modela ${ }^{20}$.

Sohail je istraživao kvalitetu usluga u privatnim bolnicama Malezije koristeći se modificiranom verzijom SERVQUAL-a. Rezultati su pokazali da percipirana vrijednost usluga nadmašuje očekivanja po svim mjerenim varijablama, kao i da Malezijci veće značenje pridaju javnim od privatnih zdravstvenih ustanova. Naime, utvrđena su niska očekivanja od liječenja u privatnim bolnicama, što se pripisuje činjenici da se većina odlučuje na liječenje u javnim ustanovama gdje je trošak medicinskih usluga znatno manji zbog 90-postotnih subvencija vlade ${ }^{21}$.

Pakdil i Harwood ispitivali su jaz između očekivanja i percepcije pacijenata u klinici za predoperacijsku procjenu u Turskoj. Primjenjujući model SERVQUAL utvrdili su da je ključna dimenzija za zadovoljstvo pacijenata „točnost informacija o anesteziji i operacijskom zahva- tu”. Druga najviše ocijenjena dimenzija bila je „prijateljstvo i ljubaznost" dok je najveći jaz ustanovljen između očekivanog i stvarnog vremena čekanja u klinici. Autori model smatraju korisnim u procijeni razlika između pacijentovih očekivanja i stvarnog iskustva nakon pružene usluge ${ }^{22}$.

Ramsara-Fowdar istraživala je kvalitetu usluga u zdravstvenom sektoru Mauricijusa. Rezultati istraživanja potvrdili su dimenzionalnost SERVQUAL-a, ali i pokazali dvije dodatne dimenzije („glavne medicinske usluge” i „profesionalizam”) koje su specifične za zdravstvene usluge ${ }^{23}$.

Karassavidou i suradnici istraživali su percepciju i očekivanja kvalitete usluga pacijenata u bolnicama sjeverne Grčke ${ }^{24}$. Prema saznanju autora, to je prvo istraživanje u Grčkoj koje primjenjuje model SERVQUAL u zdravstvenom sektoru. Rezultati analize pokazali su postojanje jaza kroz sve tri utvrđene dimenzije, sugerirajući da postoji dodatni prostor za poboljšanje kvalitete usluga. Utvrđeno je da je ljudski aspekt najvažnija dimenzija i pretkazivač cjelokupne procjene kvalitete.

Primarni razlog istraživanja koje su proveli Petrovici i Phillips bio je razvijanje i testiranje modela za ocjenu kvalitete bolničkih usluga - SERVHOSP. Istraživanje su proveli na uzorku pacijenata jedne privatne bolnice $u$ Rumunjskoj ${ }^{25}$. Model koji su razvili sastojao se prvotno od osam dimenzija, kasnije svedenih na šest. Pet od tih dimenzija poklapa se s postojećim modelom RATER, a dodatna dimenzija koja je potvrđena uzima u obzir ambijent bolnice. 
Yeşilada i Direktör ispitivali su zadovoljstvo pacijenata zdravstvenim uslugama u privatnim i javnim bolnicama sjevernog Cipra ${ }^{26}$. Utvrdili su da je jaz između percepcije i očekivanja manji u privatnim nego javnim bolnicama za sve tri postavljene dimenzije kvalitete usluga (pouzdanost - povjerenje, razumijevanje i opipljivost).

Modificirani model SERVQUAL za mjerenje kvalitete usluga testirali su Brahmbhatt i suradnici, uspoređujući očekivanu i percipiranu kvalitetu usluga u privatnim i javnim bolnicama kroz pet dimenzija s ukupno 41 tvrdnjom. Najveći jaz između percepcije i očekivanja utvrđen je za dimenziju „pouzdanost” i u privatnim i u javnim bolnicama, $s$ tim što je bio veći u privatnim bolnicama ${ }^{27}$. U sve ostale četiri dimenzije utvrđen je veći jaz između percepcija i očekivanja kod pacijenata u javnim bolnicama. Autori zaključuju da su klijenti bili nezadovoljni razinom kvalitete dobivene usluge i u privatnim i u javnim bolnicama te da se, koristeći se rezultatima proizašlih iz ovog istraživanja, mora raditi na poboljšanju kvalitete pruženih usluga.

Huseinspahić je u svojem istraživanju na uzorku pacijenata bolnice u Tuzli utvrđivao percipiranu razinu kvalitete zdravstvenih usluga i utjecaj očekivanja na razinu percipirane kvalitete u vezi s tehničkim i funkcionalnim dimenzijama kvalitete usluga te utjecaj očekivanja na razinu zadovoljstva pacijenta. Istraživanje je pokazalo da postoji znatna povezanost razine nepotvrđivanja/ potvrđivanja očekivanja, odnosno percipirane kvalitete na razinu zadovoljstva pacijenata kako funkcionalnim (rehabilitacijske usluge) tako i tehničkim dimenzijama (kirurške usluge). Kod ostalih medicinskih usluga nije dokazana ta povezanost ${ }^{28}$.

Povezanost imidža bolnice sa zadovoljstvom pacijenata kvalitetom usluga i lojalnost istražuje Wu na podacima dobivenima iz velikih privatnih bolnica u Tajvanu (29). Rezultati otkrivaju da imidž bolnice ima direktan i indirektan utjecaj na lojalnost pacijenata, odnosno pozitivan imidž bolnice ne samo da direktno povećava lojalnost nego i poboljšava zadovoljstvo pacijenta povećanjem percipirane kvalitete usluga, što dovodi do povećanja pacijentove želje za ponovnim boravkom u bolnici. Zaključak je autora da imidž bolnice doista služi kao vodeći faktor u povećanju kvalitete usluga, zadovoljstva pacijenata i lojalnosti.

U svojem istraživanju Kumaraswamy je utvrdio da su važni faktori kvalitete usluga u zdravstvenim ustanovama ponašanje liječnika, podrška osoblja, atmosfera i operativna izvedba. Percepcija faktora kvalitete usluga ima važan i pozitivan utjecaj na pacijentovu percepciju cjelokupne usluge ${ }^{30}$.
Lei i Jolibert analizirali su povezanost kvalitete, zadovoljstva i lojalnosti u kineskom zdravstvenom sustavu mjereći percipiranu kvalitetu usluga. Primijenili su model sa svega pet tvrdnji i dokazali da percipirano poboljšanje kvalitete ne dovodi izravno do lojalnosti klijenata, već da lojalnost ovisi o razini zadovoljstva pacijenata ${ }^{31}$.

Loša percepcija kvalitete usluga u javnim bolnicama Bangladeša dovela je do povećanih zahtjeva za privatnom zdravstvenom zaštitom. S obzirom na izrazit rast privatnog zdravstvenog sektora, imperativ je mjerenje kvalitete usluga u privatnim bolnicama u Bangladešu. Rahman i Kutubi proveli su istraživanje kako bi identificirali ključne faktore kvalitete usluga koji utječu na zadovoljstvo pacijenata u privatnim bolnicama te ocijenili kako pacijenti rangiraju 11 postavljenih dimenzija kvalitete usluga ${ }^{32}$.

Krishnamoorthy i Srinivasan istraživali su percepciju kvalitete bolničkih usluga u Indiji. Utvrdili su 10 dimenzija kvalitete usluga u bolnicama: „medicinska usluga”, „razumijevanje”, „prijam”, „otpust”, „fizičko okruženje”, ,jednakost”, ,infrastruktura”, „opipljivost”, „medicinska njega" i „dostupnost medicine”. Također je utvrđeno da od svih dimenzija samo opipljivost, prijam, jednakost, medicinska usluga i medicinska njega imaju znatan utjecaj na zadovoljstvo pacijenata ${ }^{33}$.

Međuodnos pacijenata i pružatelja zdravstvenih usluga od izrazite je važnosti jer izravno utječe na zadovoljstvo pacijenata. Iz tog odnosa pacijent procjenjuje kvalitetu usluga i obrnuto, pružateljima usluga daje mogućnost utjecanja na pacijentovu percepciju kvalitete usluga. Primjenjujući modificirani model SERVQUAL Peprah i Atarah ocjenjivali su zadovoljstvo pacijenata regionalne bolnice u Gani. Jedna od promatranih dimenzija bila je upravo „komunikacija / međuljudski odnosi”. Rezultati su pokazali da je cjelokupno zadovoljstvo pacijenata dobivenim uslugama dobro, ali i da postoje negativni jazovi u četiri od šest upotrijebljenih dimenzija. „Pouzdanost”, „komunikacija / međuljudski odnosi”, „sigurnost” i „odgovornost” dimenzije su koje nisu zadovoljile očekivanja pacijenata ${ }^{34}$.

Zarei i suradnici istraživali su utjecaj kvalitete usluga na zadovoljstvo pacijenata u privatnim bolnicama u Teheranu. Utvrdili su znatnu povezanost između kvalitete usluga i zadovoljstva pacijenata, pri čemu su „troškovi usluga”, „kvaliteta procesa” i „kvaliteta interakcija” imali najveći utjecaj na sveukupno zadovoljstvo pacijenata ${ }^{35}$.

Jedno od malobrojnih istraživanja mjerenja kvalitete zdravstvenih usluga u Hrvatskoj proveli su Bajto i Kondić na uzorku korisnika usluga Opće županijske bolnice u Našicama ${ }^{36}$. Utvrdili su da se model SERVQUAL može 
uspješno primijeniti u zdravstvenim institucijama te da dovodi do objektivnih pokazatelja zadovoljstva korisnika usluga na osnovi kojih se mogu poduzeti konkretne aktivnosti za njihovo poboljšanje.

Mečev i Goleš Kardum u svojem su istraživanju ispitivali pacijentovu percepciju kvalitete primarne zdravstvene zaštite, odnosno postoji li razlika između pacijentova očekivanja i razine zadovoljstva dobivenom medicinskom uslugom. Utvrdili su postojanje jaza u svim dimenzijama te da nema razlike u percepciji kvalitete usluga s obzirom na dob i spol pacijenta, no da postoji znatna razlika u razini zadovoljstva s obzirom na status zaposlenosti i učestalost korištenja uslugama ${ }^{37}$.

Ozretić Došen i suradnici u svojem radu iznose rezultate provedenog istraživanja o kvaliteti zdravstvenih usluga pruženih u ustanovama primarne zdravstvene zaštite primjenom instrumenta SERVQUAL. Rezultati su pokazali da postoji znatan jaz između percepcija i očekivanja korisnika usluga te da je jaz različit ovisno o dimenzijama. Najveći jaz zabilježen je kod dimenzija „odgovornost”, „sigurnost” i „pouzdanost” ${ }^{\text {. }}$.

\subsection{Pregled dosadašnjih istraživanja kvalitete usluga u području zdravstvenog turizma}

Empirijske su studije povezane s mjerenjem kvalitete usluge u zdravstvenom turizmu rijetke.

Snoj i Mumel mjerili su percipiranu kvalitetu usluge u slovenskim lječilištima ${ }^{39}$. Alén Gonzáles, Comesana i Brea procjenjivali su percipiranu kvalitetu usluge u španjolskim toplicama ${ }^{40}$.

Rad je sa suradnicima istraživao međuovisnost kvalitete medicinskih usluga i zadovoljstva pacijenata u medicinskom turizmu. Istraživanje je provedeno u Maleziji. Primijenjen je model SERVQUAL i utvrđena je pozitivna povezanost između kvalitete usluga i zadovoljstva pacijenata. Povezanost dimenzije opipljivosti sa zadovoljstvom nije potvrđena ${ }^{41}$.

Guiry i Vequis istraživali su očekivanja i percepcije kvalitete usluga na uzorku turista koji su putovali izvan Sjedinjenih Američkih Država kako bi konzumirali određene medicinske usluge. Njihovo istraživanje je pokazalo da postoji znatna razlika između njihovih očekivanja i percepcije kvalitete usluge u čak četiri od pet dimenzija kvalitete usluge, a najveći je raskorak kada je riječ o pouzdanosti. Jedina dimenzija gdje su se poklopila očekivanja i percepcija povezana je s odazivom na zahtjeve klijenata ${ }^{42}$.
Primjenom modela SERVQUAL Quintela, Correia i Antunes istražili su utjecaj kvalitete usluga na zadovoljstvo klijenata u zdravstvenom turizmu u Portugalu. Utvrdili su tri kvalitete usluge i dokazali da na zadovoljstvo korisnika portugalskih termalnih izvora najviše utječu sposobnost zaposlenika da djeluju pouzdano i točno, njihova volja da pomognu klijentima i pruže promptnu uslugu i individualiziranu pažnju ${ }^{43}$.

El-Refae je istraživanjem u termalnim centrima u Maleziji dokazao utjecaj kvalitete usluge na zadovoljstvo i ponavljanje kupnje. Njegovo istraživanje pokazalo je da na zadovoljstvo najviše utječu opipljivost i suosjećajnost, zatim pouzdanost i odgovornost, dok povezanost sigurnosti i zadovoljstva nije utvrđena ${ }^{44}$.

U Hrvatskoj su Marković, Horvat i Raspor istraživali percipiranu kvalitetu usluga u zdravstvenom turizmu na primjeru Thalassotherapije Opatija ${ }^{45}$. Također Marković, Raspor i Komšić uz pomoć modela SERVQUAL mjerili su kvalitetu usluga u hrvatskom wellness-turizmu ${ }^{46}$. Svrha i cilj tog istraživanja bio je teorijski istražiti koncept kvalitete usluga wellnessa, empirijski ocijeniti očekivanja i percepcije klijenata te utvrditi ukupno zadovoljstvo klijenata kvalitetom pruženih usluga wellnessa u hotelskim wellness-centrima. Za ispitivanje je bio upotrijebljen dizajnirani upitnik koji se temeljio na dimenzijama ljestvice SERVQUAL, sastavljen od tri dijela - prvi dio odnosio se na očekivanja ispitanika, u drugom dijelu ispitivala se percepcija o zadovoljstvu kvalitetom usluga, a treći se odnosio na demografske podatke. Ovim istraživanjem utvrđeno je da klijenti imaju visoka očekivanja posebno u pogledu pouzdanosti usluga i kvalitete osoblja, suosjećanja i izgleda prostora i osoblja.

Marković, Lončarić i Lončarić objavili su 2014. godine rezultate mjerenja kvalitete usluga u specijalnim bolnicama za medicinsku rehabilitaciju u Republici Hrvatskoj primjenom modela SERVQUAL. To je prvo takvo istraživanje u specijalnim bolnicama u Hrvatskoj. Rezultati provedenog empirijskog istraživanja potvrdili su prikladnost modela SERVQUAL za mjerenje kvalitete zdravstvenih usluga, a najveći jaz ostvaren je u području nemedicinskih usluga, što, navode autori, upućuje na potrebu njihova unaprjeđenja. Istraživanje je dokazalo i povezanost zadovoljstva pacijenata uslugama bolnica i njihove lojalnosti ${ }^{47}$.

Rezultati prethodnih istraživanja provedenih u različitim zemljama primjenom modela SERVQUAL upućuju na zaključak da je to koristan instrument za vrednovanje pružene kvalitete zdravstvenih usluga sa stajališta korisnika, a njegovom se primjenom otkrivaju područja u kojima su potrebna poboljšanja. 
Tablica 3. Pregled dosadašnjih istraživanja kvalitete usluga u području zdravstvenog turizma

\begin{tabular}{|c|c|c|c|}
\hline AUTOR & KONCEPTI & MODEL & DIMENZIJE \\
\hline Marković (2000) & $\begin{array}{l}\text { Kvaliteta usluga } \\
\text { Zadovoljstvo gosta }\end{array}$ & - & - \\
\hline $\begin{array}{l}\text { Snoj i Mumel } \\
\qquad(2002)\end{array}$ & Percipirana kvaliteta usluga & Prilagođeni SERVQUAL & \\
\hline $\begin{array}{l}\text { Marković, Horvat i } \\
\text { Raspor (2004) }\end{array}$ & Kvaliteta usluga & Prilagođeni SERVQUAL & $\begin{array}{l}\text { Očekivanja (efikasnost } \\
\text { isporuke usluge, } \\
\text { razumijevanje, pristup } \\
\text { uslugama, kvaliteta outputa, } \\
\text { pouzdanost) } \\
\text { Percepcija (međusobni } \\
\text { odnosi, opipljivost, } \\
\text { razumijevanje, pristupačnost, } \\
\text { kvaliteta outputa) }\end{array}$ \\
\hline $\begin{array}{c}\text { Alén Gonzáles, Comesana i } \\
\text { Brea (2007) }\end{array}$ & Percipirana kvaliteta usluge & Prilagođeni SERVQUAL & \\
\hline Rad, Som i Zainuddin (2010) & $\begin{array}{c}\text { Kvaliteta usluga } \\
\text { Zadovoljstvo klijenata }\end{array}$ & SERVQUAL & $\begin{array}{l}\text { Pouzdanost } \\
\text { Sigurnost } \\
\text { Opipljivost } \\
\text { Odaziv } \\
\text { Razumijevanje }\end{array}$ \\
\hline Marković i Raspor (2010) & Kvaliteta usluga & Prilagođeni SERVQUAL & $\begin{array}{c}\text { Kvaliteta osoblja i } \\
\text { pouzdanost usluge } \\
\text { Razumijevanje i sigurnost } \\
\text { Izgled opreme i osoblja }\end{array}$ \\
\hline Guiry i Vequist (2011) & Kvaliteta usluga & SERVQUAL & $\begin{array}{l}\text { Pouzdanost } \\
\text { Sigurnost } \\
\text { Opipljivost } \\
\text { Odaziv } \\
\text { Razumijevanje }\end{array}$ \\
\hline $\begin{array}{l}\text { Quintela, Correia i Antunes } \\
\text { (2011) }\end{array}$ & $\begin{array}{l}\text { Kvaliteta usluga } \\
\text { Zadovoljstvo klijenata }\end{array}$ & Prilagođeni SERVQUAL & $\begin{array}{c}\text { Posjećenost } \\
\text { Osiguranje kvalitete } \\
\text { Opipljivost }\end{array}$ \\
\hline El-Refae (2012) & $\begin{array}{c}\text { Kvaliteta usluga } \\
\text { Zadovoljstvo klijenata } \\
\text { Ponavljanje kupnje }\end{array}$ & SERVQUAL & $\begin{array}{l}\text { Pouzdanost } \\
\text { Opipljivost } \\
\text { Sigurnost } \\
\text { Odaziv } \\
\text { Razumijevanje }\end{array}$ \\
\hline $\begin{array}{l}\text { Marković, Raspor i Komšić } \\
\text { (2012) }\end{array}$ & Kvaliteta usluga & Prilagođeni SERVQUAL & $\begin{array}{c}\text { Opipljivost } \\
\text { Pouzdanost } \\
\text { Odaziv } \\
\text { Sigurnost } \\
\text { Razumijevanje }\end{array}$ \\
\hline $\begin{array}{l}\text { Marković, Lončarić i Lončarić } \\
\qquad(2014)\end{array}$ & $\begin{array}{c}\text { Kvaliteta usluga } \\
\text { Zadovoljstvo pacijenata } \\
\text { Lojalnost }\end{array}$ & Prilagođeni SERVQUAL & $\begin{array}{c}\text { Komunikacija osoblja i } \\
\text { pouzdanost } \\
\text { Sigurnost } \\
\text { Kvaliteta outputa } \\
\text { Okruženje bolnice }\end{array}$ \\
\hline
\end{tabular}




\section{Rasprava i zaključak}

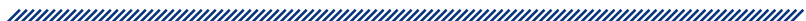

Model SERVQUAL bio je često kritiziran i preispitivala se njegova valjanost i pouzdanost. Cronin i Taylor kritizirali su upotrebu rezultata analize jazova (engl. gap analize) $u$ mjerenju kvalitete usluge i zaključili da je kvaliteta usluge mjerena samo percepcijom korisnika usluge dovoljna ${ }^{48}$. Postoje i brojna neslaganja u tome može li se skala za mjerenje kvalitete usluge univerzalno aplicirati između različitih uslužnih djelatnosti i postoji li uopće veza između zadovoljstva korisnika usluge i kvalitete. Buttle, kao i Asubonteng, ovom instrumentu pripisuje ozbiljne kritike $^{16,49}$. Buttle ih dijeli u dvije elaboracije: teorijsku i operacijsku. S teorijskog gledišta navodi primjedbu da se SERVQUAL temelji na odbijanju paradigme, kritizira model jazova navodeći da je malo pouzdanih pokazatelja da kupci ocjenjuju kvalitetu usluge u pojmovima percepcija - očekivanja. Zamjera se i to da se SERVQUAL fokusira na proces realiziranja usluge, a ne na izlaz usluge te kritizira broj dimenzija smatrajući da broj dimenzija uključuje kvalitetu usluge u kontekstu. U operacijskoj elaboraciji Buttle navodi da je pojam očekivanja ,polisemičan”, odnosno da se korisnici usluge koriste standardima radije nego očekivanjima da ocjene kvalitetu usluge. Zamjera i kompoziciju elemenata tvrdeći da četiri ili pet elemenata ne mogu „uhvatiti” sve varijacije unutar svake dimenzije kvalitete usluge, upozorava da procjene kvalitete usluge o kvaliteti mogu varirati od trenutka do trenutka te da obrnuta polarnost elemenata na skali uzrokuje greške ispitanika ${ }^{16}$.

Zeithaml, Berry i Parasuraman konstantno su radili na poboljšanju SERVQUAL-a. Ističu važnost nejasne, tj. dvosmislene prirode SERVQUAL-ovih očekivanja koje se dobiju mjerenjem odnosa između različitih standarda očekivanja i opažene kvalitete usluga te da njihov model potvrđuje da postoje dvije razine do kojih očekivanja korisnika mogu procijeniti kvalitetu usluge. Prvo, da poželjnu uslugu čini ono što korisnik usluge smatra da može i mora biti osigurano. Drugo, da odgovarajuću uslugu čini minimalna razina usluge koju je korisnik voljan prihvatiti. Ove dvije razine razdvaja zona tolerancije (engl. zone of tolerance) i definirana je kao razina performansi usluge koja se smatra zadovoljavajućom ${ }^{50}$. Koristeći se ti razlikovanjem Parasuraman, Zeithaml i Berry ${ }^{51}$ testirali su tri alternativne mjere kvalitete usluge, primjenjujući ljestvicu od 1 do 9: upitnik nazvan SERVQUAL+ ima odvojene razine poželjne, odgovarajuće i opažene usluge. Dvije kolone predstavljaju izravnu razinu nesklada između poželjne i opažene usluge te između opažene i odgovarajuće usluge, a jedna kolona mjeri izravnu razinu između poželjne i opažene usluge. Takav format s tri kolone osigurava detaljnije podatke koji pomažu ostvarivanju željene razine usluga te osiguravaju dovoljno informacija za odgovarajuća poboljšanja.

Unatoč kritikama, model SERVQUAL primjenjuje se u uslužnim djelatnostima. Ističe se da informacije o jazovima između internih i eksternih kvaliteta usluge mogu pomoći menadžerima, odnosno pružateljima usluga da dijagnosticiraju gdje se najbolje mogu ostvariti poboljšanja. Najveći negativni jazovi, kombinirani s procjenom najvećih očekivanja, olakšavaju određivanje prioriteta u poboljšavanju kvalitete usluga. Cilj je menadžera smanjiti raskorak (jaz), uvažavajući da je ono što se mjeri percipirana kvaliteta, koja uvijek predstavlja prosudbu korisnika usluga.

Ovo istraživanje još jednom je potvrdilo da je koncept kvalitete zdravstvenih usluga višedimenzionalan te da je uz primjenu modela SERVQUAL moguće na jednostavan i učinkovit način saznati očekivanja, potrebe i želje korisnika zdravstvenih ustanova, kao i njihove stavove o dobivenim uslugama, a zatim ih iskoristiti u svrhu kreiranja kvalitetne ponude. Rezultati ovog istraživanja potvrdili su da je koncept zdravstvenih usluga višedimenzionalan. Potrebe, zahtjevi i očekivanja korisnika stalno se mijenjaju pa je potrebno kontinuirano provoditi mjerenja kako bi se znalo što korisnici očekuju te zadovoljava li pružena usluga u svakom segmentu njihove potrebe i očekivanja.

\section{Literatura}

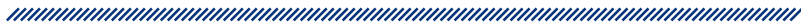

1. World Health Organization. The World health report 2000: Health systems: improving performance. Geneva: World Health Organization, 2000.

2. Donabedian A. The quality of care: how can it be assessed? Arch Pathol Lab Med. Nov 1997; 121(11):1145-1150.

3. Steffen GE. Quality Medical Care. A definition. JAMA. 1988: 260(1):56-61.

4. Lohr KN, Schroeder SA. A strategy for quality assurance in Medicare. New Engl J Med. 1990; 322(10):707-712.

5. Øvretveit J. A comparison of approaches to health service quality in the UK, USA \& Sweden and of the use of organizational audit frameworks. Eur J Public Health. 1994; 4(1):46-54. 
6. Institute of Medicine. Medicare: A Strategy for Quality Assurance, Volume I. Washington DC: The National Academies Press, 1990.

7. World Health Organization. The World health report 1999: Making a difference. Geneva: World Health Organization, 1999.

8. Legido-Quigley H, McKee M, Nolte E, Glinos IA. Assuring the quality of health care in the European Union: A case for action. Observatory Studies Series No. 12. Copenhagen: World Health Organization, 2008.

9. Woodward CA. Improving Provider Skills. Strategies for assisting health workers to modify and improve skills: developing quality health care - a process for change. Issues in health service delivery, Discussion paper No. 1. Geneva: World Health Organization, 2000.

10. Donabedian A. Evaluating the quality of medical care. The Milbank memorial fund quarterly, 1966; 44(3),166-206.

11. Braithwaite J, Healy J, Dwan K. The Governance of Health Safety and Quality: A Discussion Paper. Commonwealth of Australia, 2005.

12. Øvretveit J. A Quality costs - or does it?. Health Service Management, 1991; 87:184-185.

13. Cholewka PA. Challenges to Institutionalizing Sustainable Total Quality Management Programs in Healthcare Systems of Post-Soviet Countries. International Journal of Economic Development. 2001; 3(3).

14. Parasuraman A, ZeithamI VA, Berry LL. A Conceptual Model of Service Quality and Its Implications for Future Research. J Marketing. 1985; 49(4):41-50.

15. Parasuraman A, ZeithamI VA, Berry LL. SERVQUAL: A Multiple-Item Scale for Measuring Consumer Perceptions of Service Quality. J Retailing. 1988; 64(1):12-40.

16. Buttle F. SERVQUAL: review, critique, research agenda. Eur J Marketing. 1996; 30(1):8-32.

17. Babakus E, Mangold WG. Adapting the SERVQUAL scale to hospital services: an empirical investigation. Health Serv Res. 1992; 26(6):767-786.

18. Lam SSK. SERVQUAL: A tool for measuring patients' opinions of hospital service quality in Hong Kong. Total Qual Manage. 1997; 8(4):145-152.

19. Andaleeb SS. Public and private hospitals in Bangladesh: service quality and predictors of hospital choice. Health Policy Plan. 2000; 15(1):95-102.

20. Lee SM, Lee DH, Kang CY. The impact of high-performance work systems in the health-care industry: employee reactions, service quality, customer satisfaction, and customer loyalty. Serv Ind J. 2012; 32(1):17-36.

21. Sohail MS. Service quality in hospitals: more favourable than you might think. Manag Serv Qual. 2003; 13(3):197206.

22. Pakdil F, Harwood TN. Patient satisfaction in a preoperative assessment clinic: An analysis using SERVQUAL dimensions. Total Qual Manage. 2005; 16(1);15-30.

23. Ramsaran-Fowdar RR. Developing a service quality questionnaire for the hotel industry in Mauritius. J Vacat Mark. 2007; 13(1):19-27.
24. Karassavidou E, Glaveli N, Papadopoulos CT. Quality in NHS hospitals: no one knows better than patients. Measuring Business Excellence. 2009; 13(1):34-46.

25. Phillips PA, Petrovici DA. Conceptualising the Perceived Performance in Hospital Services: A Patient's Perspective. Working Paper No.169. Canterbury: University of Kent, 2009.

26. Yeşilada F, Direktör E. Health care service quality: A comparison of public and private hospitals. Afr J Bus Manag. 2010; 4(6):962-971.

27. Brahmbhatt M, Baser N, Joshi N. Adapting the SERVQUAL scale to hospital services: An empirical investigation of patients' perceptions of service quality. International Journal of Multidisciplinary Research. 2011; 1(8):27-42.

28. Huseinspahić N. Kvalitet kao pretpostavka za zadovoljstvo pacijenata. South Eastern Europe Health Sciences Journal (SEEHSJ). 2011; 1(1):67-73.

29. Wu CC. The impact of hospital brand image on service quality, patient satisfaction and loyalty. Afr J Bus Manag. 2011; 5(12):4873-4882.

30. Kumaraswamy S. Service Quality in Health Care Centers: An Empirical Study. International Journal of Business and Social Science. 2012; 3(16):141-150.

31. Lei $\mathrm{P}$, Jolibert A. A three-model comparison of the relationship between quality, satisfaction and loyalty: an empirical study of the Chinese healthcare system. BMC Health Serv Res. 2012; 12:436-447.

32. Rahman R, Kutubi SS. Assessment of service quality dimensions in healthcare industry: A study on patient's satisfaction with Bangladeshi private Hospitals. International Journal of Business and Management Invention. 2013; 2(4):59-67.

33. Krishnamoorthy V, Srinivasan R. Measuring Patient's Perceived Service Quality For Multispeciality Hospital. Research Journal of Commerce and Behavioural Science. 2014; 3(5):59-69.

34. Peprah AA, Atarah BA. Assessing Patient's Satisfaction Using SERVQUAL Model: A Case of Sunyani Regional Hospital, Ghana. International Journal of Business and Social Research. 2014; 4(2):133-143.

35. Zarei E, Daneshkohan A, Pouragha B, Marzban S, Arab M. An Empirical Study of the Impact of Service Quality on Patient Satisfaction in Private Hospitals, Iran. Global Journal of Health Science. 2015; 7(1):1-9.

36. Bajto M, Kondić Ž. Mjerenje zadovoljstva korisnika usluge SERVQUAL modelom na primjeru opće bolnice. U: Zbornik sažetaka radova 6 . Hrvatske konferencije o kvaliteti „Kvaliteta i organizacijska kultura”, Opatija, 18.20.5.2005. Zagreb: Hrvatsko društvo za kvalitetu; 2005. [pristupljeno 7.1.2013.]. Dostupno na: http://issuu.com/ kvaliteta.net/docs/bajto_m_rad

37. Mečev D, Kardum Goleš I. Primary healthcare service quality measurement: SERVQUAL scale. Ekonomski vjesnik. 2015; 28(1):161-177.

38. Ozretić Došen $Đ$, Škare V, Škare T. Mjerenje kvalitete usluge primarne zdravstvene zaštite SERVQUAL instrumentom. Rev soc polit. 2010; 17(1):27-44. 
39. Snoj B, Mumel D. The measurement of perceived differences in service quality - the case of health spas in Slovenia. J Vacat Mark. 2002; 8(4):362-379.

40. Alén González ME, Comesana LR, Brea JAF. Assessing tourist behavioral intentions through perceived service quality and customer satisfaction. J Bus Res. 2007; 60(2):153-160.

41. Rad NF, Som APM, Zainuddin Y. Service Quality and Patients' Satisfaction in Medical Tourism. World Applied sciences Journal 10 (Special Issue of Tourism \& Hospitality). 2010; 10(1):24-30.

42. Guiry M, Vequist DG. Travelling abroad for medical care: U.S. medical tourists' expectations and perceptions of service quality. Health Mark Q. 2011; 28(3):253-269.

43. Quintela JA, Correia AG, Antunes JG. Service quality in health and wellness tourism-trends in Portugal. International Journal of Business, Management and Social Sciences. 2011; 2(3):1-8.

44. Al-Alaq BA, El-Refae GA. The Relationships between Service Quality, Satisfaction, and Behavioral Intentions of Malaysian Spa Center Customers. International Journal of Business and Social Science. 2012; 3(1):198-205.

45. Marković S, Horvat J, Raspor S. Mjerenje kvalitete usluga u zdravstvenom turizmu=Service quality measurement in health tourism: An exploratory study. Ekonomski vjesnik. 2004;17(1-2):63-76.
46. Marković S, Raspor S, Komšić J. Mjerenje kvalitete usluga wellnessa: case study. U: Drljača M, ur. Zbornik radova 13. međunarodnog simpozija o kvaliteti „Kvaliteta i društvena odgovornost”, Hrvatsko društvo menadžera kvalitete; 15.-16.3.2012.; Solin, Hrvatska. 571-584.

47. Marković S, Lončarić D [Dina], Lončarić D [Damir]. Service Quality and Customer Satisfaction in the Health Care Industry - Towards Health Tourism Market. Tourism and Hospitality Management. 2014; 20(2):155-170.

48. Cronin JJ Jr, Taylor SA. Measuring service quality: a re-examination and extension. J Marketing. 1992; 56(3):55-68.

49. Asubonteng P, McCleary, KJ, Swan JE. SERVQUAL revisited: a critical review of service quality. Journal of Services marketing, 1996; 10(6):62-81.

50. Parasuraman A, Berry LL, Zeithaml VA. More on improving service quality measurement. J Retailing. 1993; 69(1):140-147.

51. Parasuraman A, Zeithaml VA, Berry LL. Alternative scales for measuring service quality: A comparative assessment based on psychometric and diagnostic criteria. J Retailing. 1994;70(3):201-230. 


\section{HEALTH SERVICE QUALITY CONCEPT AND MEASUREMENT}

1 Suzana Marković

1 Irena Regent Turkalj

2 Aleksandar Racz

1 Fakultet za menadžment u turizmu i ugostiteljstvu, Opatija

2 Zdravstveno veleučilište, Zagreb

\section{Summary}

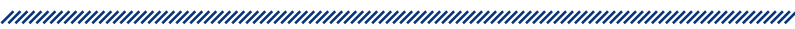

Introduction: The concept of health service quality has been researched for more than two decades, but there are still few articles in the scientific and professional practice in the Republic of Croatia which research and measure the satisfaction level of health service users.

The objectives of this article were: to define the health service quality concept, to research the models and methods for measuring health service quality, to analyse the current health service quality research carried out by international and local authors with an emphasis on research within the health system, to examine the current health service quality researches and measurements as well as the applicability of the SERVQUAL model, as the most commonly used model for measuring service quality.

Methods: A conceptual research approach was used, in which the service quality concept with an emphasis on the health service quality concept and user satisfaction were elaborated and presented from a theoretical viewpoint by using secondary data sources.
Results: The article provides a systematic overview of basic concepts of health service quality as well as the health service quality measurement models with an emphasis on the applicability of the SERVQUAL model.

Conclusion: The results of this research confirmed that the health service quality concept is multidimensional. It has once again been confirmed that with the SERVQUAL model health care service users' expectations, needs and wishes can be discovered easily and efficiently, as well as their opinion about the services provided, which are all to be used to create a high quality, improved offer.

Keywords: service quality, health service quality, customer satisfaction, SERVQUAL model, measurement 